\title{
A note on ash as indigestible dietary marker to determine digestibility of seeds in adult granivorous birds
}

\author{
J. Sales ${ }^{1}$ and G.P.J. Janssens \\ Laboratory of Animal Nutrition,Department of Animal Nutrition, \\ Genetics, Breeding and Ethology, Faculty of Veterinary Medicine, Ghent University \\ Heidestraat 19, B-9820, Merelbeke, Belgium
}

(Received 8 June 2005; revised version 12 August 2005; accepted 6 January 2006)

\begin{abstract}
A study has been conducted to evaluate the possible use of ash as indigestible dietary marker to determine energy metabolizability, nitrogen retention and digestibility of dry matter, organic matter and crude fat in seeds fed to adult granivorous birds. Digestibility values of whole maize and peas for adult domestic pigeons, and sunflower seed for adult African Grey parrots, were compared between the use of the ash ratio in seeds and excreta and the method of total collection of feed intake and excreta output. A temperature of $400^{\circ} \mathrm{C}$ was found to be optimal to obtain ash recovery values of near to $100 \%$ in both species for all seeds evaluated. Similar means and variation in values indicate that the ash ratio method could be a simple alternative to the laborious method of total collection to determine digestibility of seeds for adult granivorous bird. Precautions in the use of the ash ratio method are discussed.
\end{abstract}

KEY WORDS: ash, digestibility, seeds, granivorous birds

\section{INTRODUCTION}

Reliable measurements of the digestibility of various nutrients in feed are critical for effective animal nutrition research (De la Noüe and Choubert, 1986). Disadvantages attributed to total collection of feed intake and excreta output, the most widely accepted method to determine digestibility, have been described in detail by Sales and

\footnotetext{
${ }^{1}$ Corresponding author: e-mail: James_Sales_1@hotmail.com
} 
Janssens (2003a,b). Difficulty in collection of all wasted food and excreta is especially prominent in birds with active feeding and husking habits, such as parrots (Sales et al., 2004). Furthermore, confinement of free-flying birds such as pigeons to small enclosures might have an influence on behaviour (Sales, personal observation).

The use of an indigestible marker, where only samples of food and excreta are needed to calculate digestibility (Bjorndal, 1985), could eliminate some of the above problems. The use of whole seeds in nutrition of granivorous birds rendered the use of external markers, that have to be mixed with the diet, unsuitable (Sales and Janssens, 2003c; Sales et al., 2004). Furthermore, extremely low contents of some widely used indigestible markers inherent to feed ingredients, such as acidinsoluble ash and lignin, occur in seeds commonly fed to granivorous birds. This caused analytical errors that result in unrealistic nutrient digestibility values when used in both pigeons (Sales and Janssens, 2003c) and parrots (Sales et al., 2004).

Due to simplicity, several studies with invertebrates, fish, reptiles and mammals (Bjorndal, 1985) have applied the ash ratio technique since its introduction in 1966 by Conover. However, among the several reasons why ash is denied as dietary marker, especially in domesticated species, is that it contains several minerals that are digested by the animal's body for growth and maintenance. Some of the minerals are excreted back into the intestines and will not interfere with the use of ash as marker. Another disadvantage is that ash can be dissolved and lost in either a gas or liquid phase during passage through the digestive system (Bjorndahl, 1985). No information could be obtained regarding the use of ash as indigestible marker in avian species. A study has been conducted to evaluate the possible use of ash as dietary marker in adult granivorous birds that are fed on seeds.

\section{MATERIAL AND METHODS}

Apparent metabolizable energy $\left(\mathrm{AME}_{\mathrm{n}}\right)$ corrected for total nitrogen retained or lost from body tissue to nitrogen $(\mathrm{N})$ equilibrium using a factor of $34.39 \mathrm{~kJ} / \mathrm{g} \mathrm{N}$ retained (Hill and Anderson, 1958), $\mathrm{N}$ retention and apparent digestibility of dry matter (DM), organic matter, and crude fat in whole maize $(88.94 \%$ DM; $7.56 \%$ crude protein on DM basis) and peas $(86.44 \% \mathrm{DM} ; 19.91 \%$ crude protein on DM basis) were determined with 20 adult domestic pigeons through the method of total collection of feed intake and excreta output, as described in detail by Sales and Janssens (2003c). A similar experiment on nutrient digestibility of sunflower seed (92.83\% DM; $17.09 \%$ crude protein on DM basis) has been conducted with six adult African Grey parrots, as described by Sales et al. (2004). As parrots dehusked sunflower seed before swallowing, intake was calculated from contents in feed offered and feed refusals (hulls). 
The experimental set-up and housing conditions in all trials were approved by the Ethical Committee of the Faculty of Veterinary Medicine of Ghent University.

Despite slight modifications to accommodate the calculation of $\mathrm{AME}_{\mathrm{n}}$ and $\mathrm{N}$ retention, apparent digestibility coefficients were calculated according to standard formulas for the total collection and marker methods (Maynard and Loosli, 1969):

Total collection

Digestibility $=($ Nutrient intake - Nutrient output $) \times$ Nutrient intake

Marker method (ash ratio)

$$
\text { Digestibility }=1-\frac{\% \text { ash in feed }}{\% \text { ash in excreta }} \times \frac{\% \text { nutrient in excreta }}{\% \text { nutrient in feed }}
$$

Ash was determined by combustion of a about $2 \mathrm{~g}$ freeze-dried sample of feed or excreta for a period of $12 \mathrm{~h}$ in a muffle furnace. Dry matter, organic matter, nitrogen and crude fat contents were determined according to the AOAC (1980), whereas gross energy was determined using an IKA C-7000²-type adiabatic bomb calorimeter.

Paired t-tests were used to compare between values obtained by total collection and the ash ratio.

\section{RESULTS}

In a preliminary study an ashing temperature of $400^{\circ} \mathrm{C}$ was found to give ash recoveries in whole peas and sunflower seeds of near $100 \%$ for pigeons and parrots, respectively (Table 1).

Table 1 . Recovery of ash $(\%$, mean $\pm \mathrm{SD})$ at different ashing temperatures

\begin{tabular}{lccc}
\hline & \multicolumn{3}{c}{ Temperature, ${ }^{\circ} \mathrm{C}$} \\
\cline { 2 - 4 } & 400 & 600 & 800 \\
\hline $\begin{array}{c}\text { Pigeons } \\
\text { whole peas }(\mathrm{n}=10)\end{array}$ & $103.98 \pm 2.10$ & $98.41 \pm 4.10$ & $95.80 \pm 1.67$ \\
$\begin{array}{c}\text { Parrots } \\
\text { sunflower seed }(\mathrm{n}=6)\end{array}$ & $100.59 \pm 1.74$ & $85.34 \pm 1.22$ & $79.02 \pm 1.14$ \\
\hline
\end{tabular}

Despite a similar ash recovery rate at 600 than $400^{\circ} \mathrm{C}$ in peas for pigeons, the former has resulted in increased variation. Furthermore, comparative results at 
$400^{\circ} \mathrm{C}$ in sunflower seed for parrots, has led to the acceptance of the latter ashing temperature.

Although digestibility coefficients were different between methods for whole maize in pigeons $(\mathrm{P}<0.05)$, these differences had similar variation (Table 2$)$ and were of limited practical value.

Table 2. Values (mean $\pm \mathrm{SD}$ ) determined with either total collection or the ash ratio

\begin{tabular}{|c|c|c|}
\hline & Total collection & Ash ratio \\
\hline \multicolumn{3}{|l|}{$\begin{array}{l}\text { Pigeons } \\
\quad \text { whole maize }(\mathrm{n}=10)\end{array}$} \\
\hline $\mathrm{AME}_{\mathrm{n}}, \mathrm{MJ} / \mathrm{kg}$ & $15.81 \pm 0.05$ & $15.85 \pm 0.04$ \\
\hline $\begin{array}{l}\mathrm{N} \text { retention, } \mathrm{mg} / \mathrm{g} \text { diet } \mathrm{N} \\
\text { digestibility, } \%\end{array}$ & $3.69^{b} \pm 0.26$ & $4.25^{\mathrm{a}} \pm 0.23$ \\
\hline dry matter & $84.17^{\mathrm{b}} \pm 0.27$ & $85.23^{\mathrm{a}} \pm 0.20$ \\
\hline organic matter & $85.32^{b} \pm 0.25$ & $86.31^{\mathrm{a}} \pm 0.19$ \\
\hline crude fat & $90.03^{b} \pm 0.74$ & $90.72^{\mathrm{a}} \pm 0.64$ \\
\hline \multicolumn{3}{|l|}{ whole peas $(n=10)$} \\
\hline $\mathrm{AME}_{\mathrm{n}}, \mathrm{MJ} / \mathrm{kg}$ & $13.04 \pm 0.07$ & $13.10 \pm 0.06$ \\
\hline $\begin{array}{l}\mathrm{N} \text { retention, } \mathrm{mg} / \mathrm{g} \text { diet } \mathrm{N} \\
\text { digestibility, } \%\end{array}$ & $2.55 \pm 0.62$ & $3.67 \pm 0.52$ \\
\hline dry matter & $63.78 \pm 0.52$ & $65.11 \pm 0.39$ \\
\hline organic matter & $65.64 \pm 0.50$ & $66.90 \pm 0.38$ \\
\hline crude fat & $78.82 \pm 0.73$ & $79.58 \pm 0.83$ \\
\hline \multicolumn{3}{|l|}{$\begin{array}{l}\text { Parrots } \\
\quad \text { sunflower seed }(\mathrm{n}=6)\end{array}$} \\
\hline $\mathrm{AME}_{\mathrm{n}}, \mathrm{MJ} / \mathrm{kg}$ & $25.94 \pm 0.18$ & $26.14 \pm 0.08$ \\
\hline $\begin{array}{l}\mathrm{N} \text { retention, } \mathrm{mg} / \mathrm{g} \text { diet } \mathrm{N} \\
\text { digestibility, \% }\end{array}$ & $7.77 \pm 0.92$ & $9.42 \pm 0.52$ \\
\hline dry matter & $67.07 \pm 0.41$ & $67.22 \pm 0.61$ \\
\hline organic matter & $70.65 \pm 0.41$ & $70.35 \pm 0.64$ \\
\hline crude fat & $96.93 \pm 0.13$ & $96.98 \pm 0.14$ \\
\hline
\end{tabular}

$\mathrm{AME}_{\mathrm{n}}=$ apparent metabolizable energy corrected for nitrogen retention

a,b values with different superscripts $a, b$ in the same row are significantly different $(\mathrm{P}<0.05)$

\section{DISCUSSION}

The possible use of ash as indigestible diet marker in digestibility studies with adult granivorous birds fed on seeds has been demonstrated in this study. Despite a small increase in values determined through the ash ratio method compared to total collection, the latter should not be applied as the standard in digestibility studies. The use of the ash ratio technique resulted in similar variation than obtained through the method of total collection. 
The use of ash as indigestible marker is based on the assumption that ash is either indigestible, or the study animal is in mineral balance, therefore mineral intake will equal mineral output (Bjorndahl, 1985). Present results indicate that birds have been either in mineral balance (ash recovery around $100 \%$ ), or that excretion of minerals back into the intestines was slightly higher than absorption $(>100 \%)$. A lower ash recovery rate at ashing temperatures of 600 and $800^{\circ} \mathrm{C}$ could be ascribed to volatilization of certain minerals (Misra et al., 1993), such as phosphorus, selenium and potassium, at high temperatures.

Application of the above technique warrants further investigation. The accuracy of a marker varies among species and diets fed to the same species (Bjorndahl, 1985). The physiological condition of the species, such as stage of maturing and reproductive status that result in mineral digestion, needs consideration. Contamination during analysis should be avoided, and all analytical protocols, such as ashing temperature, kept constant. Further studies are needed on the chemical and thermal stability of the individual minerals in ash contents during passage through the digestive tract, especially in diet ingredients high in ash content. The possibility to relate digestibility to seed selection in mixtures presents a challenging opportunity.

\section{ACKNOWLEDGEMENTS}

Versele-Laga nv, Kapellestraat 70, B-9800 Deinze, Belgium, is acknowledged for provision of feed during this study.

\section{REFERENCES}

AOAC, 1980. Official Methods of Analysis, Association of Official Analytical Chemists. $13^{\text {th }}$ Edition. Arlington, VA

Bjorndal K.A., 1985. Use of ash as an indigestible dietary marker. Bull. Mar. Sci. 36, 224-230

Conover R.J., 1966. Assimilation of organic matter by zooplankton. Limnol. Oceanogr. 11, 338-345

De la Noüe J., Choubert G., 1986. Digestibility in rainbow trout: comparison of the direct and indirect methods of measurement. Prog. Fish-Cult. 48, 190-195

Hill F.W., Anderson D.L., 1958. Comparison of metabolizable energy and productive energy determinations with growing chickens. J. Nutr. 64, 587-603

Maynard L.A., Loosli J.K., 1969. Animal Nutrition. $6^{\text {th }}$ Edition, McGraw-Hill, New York, NY, pp. 613

Misra M.K., Ragland K.W., Baker A.J., 1993. Wood ash composition as a function of furnace temperature. Biomass Bioenerg. 4, 103-116

Sales J., Janssens G.P.J., 2003a. The use of markers to determine energy metabolizability and nutrient digestibility in avian species. World Poultry Sci. J. 59, 314-327

Sales J., Janssens G.P.J., 2003b. Acid-insoluble ash as a marker in digestibility studies: a review. J. Anim. Feed Sci. 12, 383-401 
Sales J., Janssens G.P.J., 2003c. Methods to determine metabolizable energy and digestibility of feed ingredients in the domestic pigeon (Columba livia domestica). Poultry Sci. 82, 1457-1461

Sales J., De Schutter L., Janssens G.P.J., 2004. The use of internal markers to determine metabolizable energy and digestibility of diets in the African Grey Parrot (Psittacus erithacus). Flemish Vet. J. 73, 176-181 